Article

\title{
Towards More Effective Water Quality Governance: A Review of Social-Economic, Legal and Ecological Perspectives and Their Interactions
}

\author{
Susanne Wuijts ${ }^{1,2, *(1)}$, Peter P. J. Driessen ${ }^{2}$ (1) and Helena F. M. W. Van Rijswick ${ }^{3}$ \\ 1 National Institute for Public Health and the Environment (RIVM), P.O. Box 1, 3720 BA Bilthoven, \\ The Netherlands \\ 2 Copernicus Institute of Sustainable Development, Utrecht University, P.O. Box 80115, 3508 TC Utrecht, \\ The Netherlands; p.driessen@uu.nl \\ 3 Utrecht Centre for Water, Oceans and Sustainability Law, Utrecht University, Newtonlaan 231, \\ 3584 BH Utrecht, The Netherlands; h.vanrijswick@uu.nl \\ * Correspondence: susanne.wuijts@rivm.nl; Tel.: +31-6-110-79638
}

Received: 30 January 2018; Accepted: 19 March 2018; Published: 22 March 2018

\begin{abstract}
In this article, social-economic, legal and ecological perspectives on effectiveness of water quality governance and their interactions have been studied. Worldwide, authorities are facing the challenge of restoring and preserving aquatic ecosystems in accordance with the United Nations Sustainable Development Goals (SDG 6). Over the last few decades, governance approaches have often been used to realise these ambitions. To date, scholars have identified that it is difficult to relate governance approaches to water quality improvement and have offered several different explanations for this. Combined with a targeted conceptualisation of the perspectives and their interactions, the systematic literature review demonstrates the gap that exists in the current understanding of these interactions and what their effects are on water quality improvement, especially in regard to the identification of ecological issues and their boundary conditions for the legal framework and the development of measures and follow-up. The review also reveals that the scientific debate is focused on the planning rather than implementation phase. A step forward can be made by supplementing existing analytical frameworks by the interactions between the different perspectives, especially those related to problem definition and the development and realisation of measures.
\end{abstract}

Keywords: effectiveness; governance; social-ecology; water law; water quality; freshwater ecosystems

\section{Introduction}

The restoration and preservation of freshwater ecosystems is a worldwide multifaceted challenge, but, as well as the complexities of the water systems and the behaviour of natural life within those systems, there are also multiple societal and institutional drivers that add to this complexity (e.g., [1,2]). As water is such an important carrier of planetary life, the restoration and preservation of freshwater ecosystems is one of the UN Sustainable Development Goals (SDG 6, http:/ / www.un.org/ sustainabledevelopment/), which aim to protect and restore water-related ecosystems by 2020.

In Europe, the ecological ambitions for water were set out in the European Water Framework Directive (WFD, 2000/60/EC), which referred to water as 'a heritage which must be protected, defended and treated as such' (2000/60/EC, recital 1). Member States (MS) were told to achieve a 'good ecological and chemical status' for all their waters by 2015, focussing on specific elements like the integrated river basin approach, the role of stakeholders and the importance of balancing the costs and benefits of water services. These objectives are in line with SDG 6 although with a different timeframe. If the WFD objectives could not be met by 2015, the WFD sets out a strict set of conditions 
for exemptions running until 2027: technically unfeasible within the timescale, disproportionately expensive, or natural conditions do not allow timely improvement (2000/60/EC, Article 4, sub 4) [3]. Unbalanced costs and benefits of water services, however, would only be accepted as an exemption if the WFD objectives had already been met [4].

To date, it can be concluded that most MS are struggling to realise the ecological ambitions of the WFD (Article 4) [1,5-10] and thus SDG 6. The European Commission (EC) reports that ' $\ldots$ in one third of the MS more than $50 \%$ of all natural surface water bodies have good or high ecological status and in $20 \%$ of the MS less than $20 \%$ of water bodies have a good ecological status ... ' [9].

Scholars offer different explanations for this result. For instance, there is a lack of comparable data on both ecological status and the effect of measures at both the national and EU level, which hampers the formulation of effective measures [1]. Policy-makers demonstrate limited ambitions because of uncertainties about the implications $[8,11]$ and MS interpret their legal obligations in different ways, which results in different levels of water quality [10]. These issues can be identified all over Europe and beyond [12-14]. Yet, where does that leave the policy-maker and the water manager who have to decide how to respond to the stagnating ecological ambitions?

Governance approaches, with the involvement of multiple actors at multiple levels, are often regarded to be more effective in dealing with complex water issues, compared to conventional legal frameworks with top-down central steering mechanisms [15-17]. In this context, governance is defined as a process of interaction between public and/or private actors ultimately aiming at the realisation of collective goals [18]. The challenges set by these multi-actor, multi-level governance approaches have been described extensively in literature (e.g., [12,13,19-21]).

Several authors have described the difficulty of identifying how governance conditions could result in better water quality in practice [7,22-25]. The variety of explanations for the difficulty of meeting the WFD objectives reflects that different scholars hold different perspectives to explain the system's effectiveness. In general, input from ecological (ecosystem behaviour), legal (legal framework, instruments, competent authorities) and social-economic (stakeholder involvement, societal values, legitimacy) disciplines can be recognised in governance approaches (e.g., [26,27]). The interactions between ecology and society, have been studied in the field of social ecology by multiple scholars (e.g., [28-32]). In this interdisciplinary field of research various focal points can be identified, from biosphere stewardship and resilience [28,29], to societal, real-world, challenges in their context [30,31], to the impact of social-ecology on public health [32]. On the local scale, social-ecology studies seem to have been dominantly focused on the interaction with stakeholders on local knowledge on ecological issues and the role of other values and interests in the governance process. However, there seems to be limited knowledge about the similarities and differences in all three perspectives of these disciplines when it comes to the effectiveness of water quality governance. There also appears to be a gap in the understanding of how these perspectives interact. This could be an important reason for why water quality improvement has been hampered in many river basins worldwide.

In this paper, we aim to contribute to the understanding of the interactions between society (from the social-economic and legal perspective) and ecology with the aim to identify how these interactions contribute to water quality improvement. A systemic analysis of these different perspectives may offer insights that cannot be identified from one of these perspectives alone and the interactions may be important conditions for achieving water quality improvement. To this end, we have built a conceptualisation of the perspectives and their interactions, and tested it using data from a systematic literature review and examples from experiences with implementing the WFD in the Netherlands. The central question for this analysis is whether water quality governance is more effective in realising the ecological ambitions if ecological, legal and social-economic perspectives are aligned somehow in a systemic way in both the planning and the implementation process. We focus our analysis on the ecological objectives of Article 4 of the WFD. Ecological ambitions reflect both WFD objectives and SDG 6 objectives. 


\section{Approach and Methods}

To address our central question, three consecutive steps are undertaken. First, the ecological, legal and social-economic perspectives on effectiveness are described using the ecological objectives of the WFD as a guiding principle. Secondly, these perspectives are conceptualised in an overarching framework to identify the interactions between them. Finally, a literature review is carried out to identify the knowledge on the different perspectives and their interactions and how they are related to current debates on water quality illustrated by examples from the WFD implementation in the Netherlands. The results are discussed and reflected upon using elements commonly regarded as practices of good water governance [27]. Does the conceptualisation of the interactions offer new insights that contribute to the understanding of how water quality improvement can be realised? What questions need to be addressed to operationalise the interactions identified in this framework?

The challenges to realising water quality improvement in river basins is not limited to the European continent but can be recognised worldwide. The range of the literature review, therefore, was wide, in order to gather studies of experiences from a variety of ecological, legal and social-economic circumstances. The review was carried out using the search engines Google Scholar, Scopus, Web of Science and Science Direct on the terms 'water quality' and 'governance'. An earlier review of WFD Implementation made by Boeuf and Fritsch [33] was also used, as well as legal literature based upon EC publications, case law from the European Court of Justice (ECJ) and follow-ups of references in the articles studied. The abstracts of all these titles have been scan-read on their potential relevancy. Abstracts on water quantity aspects (including climate change), water supply and infrastructure, microbiology, sea water, sanitation and reuse or no water at all, were excluded. The resulting papers report in their abstracts on effectivity from an ecological, legal or social perspective, or a combination of these perspectives.

This resulted in a list of 122 articles (see Supplementary Materials), each of which uses one or more perspectives, implicitly or explicitly. Based upon the abstract, title and key words, an initial identification was made as to which of the perspectives were used in the article. If there was uncertainty regarding this observation, the full article was read and the qualification adjusted accordingly. Cross-checks in between the authors have been used to check on consistency of the assessment. Articles (and their full content) using two or more perspectives were used to describe the interactions and their contribution to water quality.

One of the restrictions of this approach is that grey literature is only included on a limited basis; another is that the search focused on English-language publications only. These limitations set constraints on the results, especially with regard to legal and ecological studies, as these are often nation-based, written in the national language and they are not found by search engines such as Scopus. Despite these limitations, the resulting list of papers does offer a wide overview of how scientific literature addresses the ecological, legal and social-economic perspectives on water quality governance and their interactions so far.

\section{Three Perspectives on the Effectiveness of Water Quality Governance}

In order to identify the interactions between the ecological, legal and social-economic perspectives, the characteristics of these perspectives on the effectiveness of water quality governance were described first. The ecological objectives of the WFD were used as guiding principles, but other water quality objectives could be also characterised in a similar way. Table 1 gives a summary of these characteristics. 
Table 1. Characteristics of the ecological, legal and social-economic perspectives on the effectiveness of water quality governance.

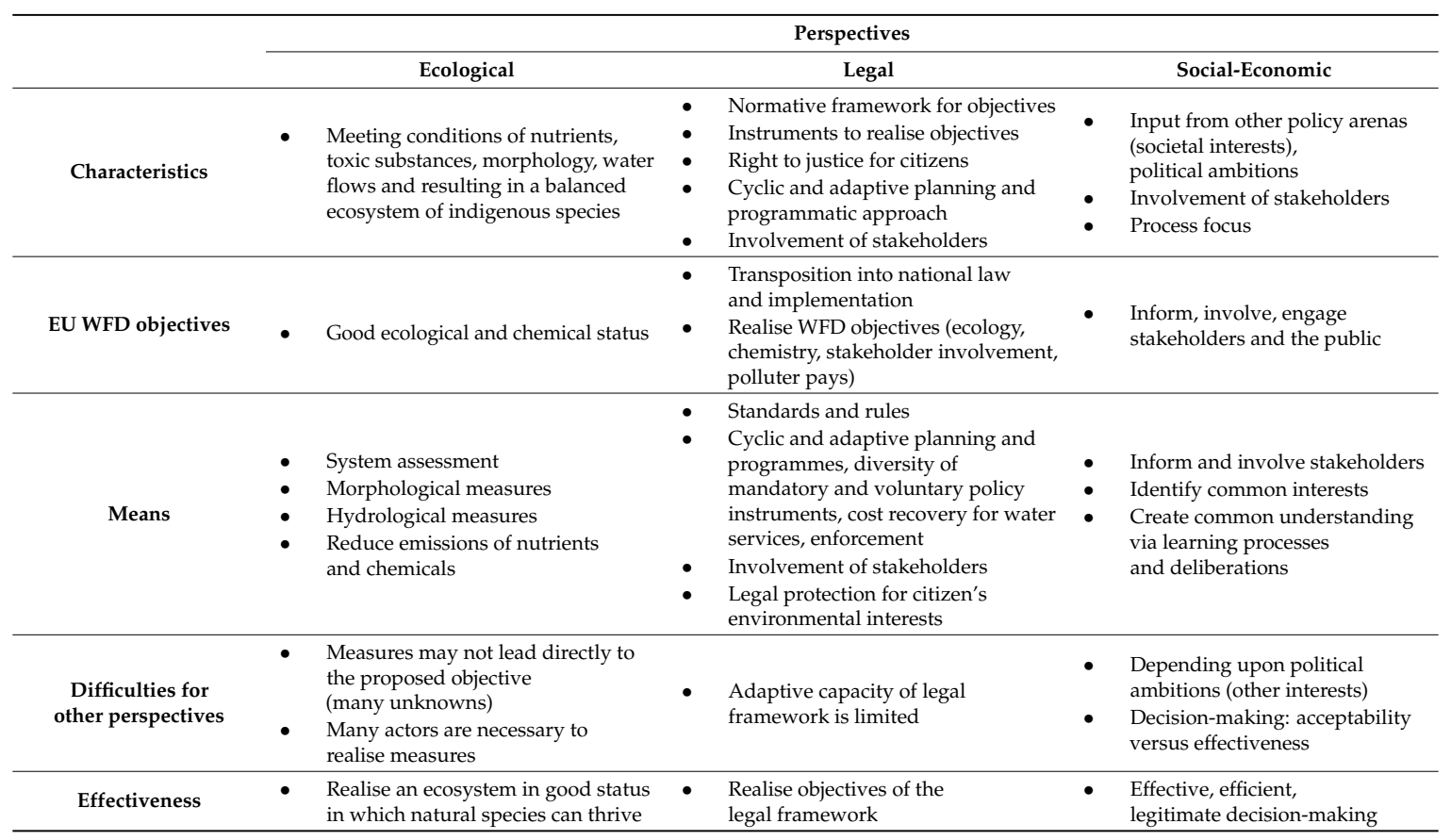

\subsection{Ecological Perspective}

From an ecological perspective, water quality governance is effective if a good status of the ecosystem is realised and preserved. To achieve this, the conditions of the ecosystem have to be in such a state that indigenous species can thrive. The hydrology of the water system itself and multiple variables like nutrient run-off, emissions of toxic substances, hydromorphological modifications to the natural state of the waterbody and overfishing, all affect the status of an ecosystem. Addressing each of these variables has its own specific challenges $[1,34]$.

The WFD aims to realise a 'good ecological and chemical status' for the different inland waters in Europe. After its introduction in 2000, ecologists at both national and regional levels elaborated these ambitions into biological and chemical objectives for specific types of waterbodies. The achievement of this 'good ecological and chemical status' depends upon many-often locally specific—variables within the ecosystem. MS have devised an assessment method for determining the ecological status of its waterbodies (also referred to as 'characterisation') and developed river basin management plans to follow up on this assessment (WFD, 2000/60/EC).

To serve agricultural, urban planning and water transport services, water systems have been modified at the expense of maintaining favourable conditions for freshwater biodiversity. The hydrology of the water system determines the extent to which chemicals can be diluted and thus affect water quality [35]. Nutrients, originating from both humans, industrial and agricultural sources, enter the environment via both point source and diffuse routes. Measures can be taken at river basin level or national level by issuing general rules for the use of manure or emissions of nitrate by waste water treatment plants. Measures can also be specific for a region, thus requiring specific knowledge on the hydrology of the water system and substance flow in order to trace the source of emission and to develop effective reduction measures e.g., on the planting schemes applied at specific locations in the basin. Man-made chemicals occur in the environment commonly which can contribute to the loss of freshwater biodiversity, but the causal link between biodiversity and specific chemicals or mixtures remains a challenge that can, as yet, only partly be explained (e.g., [36]). In addition, new chemicals come up very frequently [37], with often unknown risks, and thus require new perspectives on how to deal with them $[2,38]$. 
The variables of an ecosystem provide the options for a water authority to act upon. During the first planning cycle of the WFD, water authorities throughout Europe invested on a large scale in the development of hydromorphological measures, e.g., nature-friendly water banks [19,39-41]. Although their positive influence seems apparent, the effects of these measures on ecological objectives remain somewhat unclear. Moreover, even if all the variables in the freshwater ecosystem are moving toward more favourable conditions, it is not self-evident that this will result in a good ecological status, especially as the biological response to restoration measures in rivers is complex with many unknowns and changes could continue to occur for some time [1].

\subsection{Legal Perspective}

From a legal perspective, water quality governance is effective if the objectives of the legal framework are met. To realise this, the competent, often national, authority sets a normative framework to anchor the objectives and develops instruments such as planning, licensing, cost recovery [42] and reporting and enforcement, to enable authorities involved to meet the objectives and to provide legal protection for its citizens [43]. Within a transboundary river basin, multiple national authorities can be involved, creating another level of complexity towards the realisation of water quality objectives $[3,10]$.

The WFD sets time-bound objectives for its waters and describes the planning, programming and reporting obligations that have to be met in the process towards the realisation of these objectives. The WFD also imposes obligations on MS regarding public participation, distinguishing three levels: inform, involve and engage (Article 14). EU environmental law aims to establish a framework of obligations for public authorities and rights for its citizens [44]. Given the wide range of local variations in water and ecosystems, the WFD leaves it to the discretion of MS to formulate specific environmental quality standards for the ecological status of its waterbodies in order to achieve the general objectives of the WFD. MS should transpose WFD objectives into legally binding normative values and ensure that proper decision-making regarding the directive is made by competent authorities and that the necessary means to facilitate this are provided. This includes an adaptive planning and programmatic approach, a diversity of voluntary and mandatory policy instruments, including cost recovery for water services. After examining comparative assessments of the WFD implementation in multiple MS, it is clear that there are substantial differences in implementation approaches $[6,10,41]$ resulting in a serious risk for effectiveness in practice, especially if these differences occur in transboundary river basins. The river basin approach, introduced to address water quality issues effectively, forces MS to cooperate and share responsibilities in a river basin, while objectives of the WFD have to be met by MS individually $[4,45,46]$.

The Aarhus Convention [47] obliges MS to guarantee three categories of rights to their citizens and their associations, namely, the right of access to information, the right to participate and the right of access to justice in regard to environmental matters. The right to justice includes both procedural (e.g., the access to, or participation in, planning processes) and substantive rights (protection of one's health via EU environmental legislation) and is not limited to immediate threats [44]. All of these rights are of relevance if an individual or an NGO (non-governmental organisation) wishes to call upon a MS to take necessary action to realise WFD objectives. ECJ case law, to date, shows both questions related to access to justice as to the importance of EU law and especially the principle of effectiveness. National programmes should contain appropriate and coherent policies and measures capable of reducing emissions to the levels required by emissions ceilings (e.g., C-266/99, C-165 to $167 / 09, \mathrm{C}-237 / 07)$. This level of scrutiny is required in all environmental compartments, according to the European Commission [44].

The realisation of WFD objectives should be regarded as an obligation of result (C-461/13) and, as such, the legal perspective towards effectiveness. However, if objectives cannot be met, the WFD offers some options to extend the deadline (Article 4, sub 4) or to develop less stringent objectives based on natural conditions, disproportionate costs, technical feasibility (Article 4, sub 5) and modifications to the water system based on other overriding public interests for each individual waterbody (Article 
4, sub 7). WFD states that MS have to explicitly motivate and report these exemptions (Article 4, subs $4,5,7)$.

\subsection{Social-Economic Perspective}

From a social-economic perspective, water quality governance is effective if the societal decision-making on water quality improvement is effective, efficient and legitimate. Compliance with policy objectives may be achieved by incentives, regulation and enforcement or by voluntary measures based upon moral grounds [48]. Legitimacy in this context reflects the moral dimension of compliance [49]. Involvement of stakeholders at different levels of decision-making with different priorities and balancing different interests from other policy arenas like economic development can be regarded as the challenges facing effective water quality governance from a social-economic perspective.

The WFD aims to inform, involve and engage stakeholders and the public in order to realise its objectives (2000/60/EC, Article 14). This is said to provide for a better-informed general public, a legitimate programme of measures, more efficient implementation plans and fewer conflicts among stakeholders [50,51]. The wording chosen by the European Parliament and the Council of the European Union leaves MS room for interpretation. The experiences so far have been described in multiple publications and show that MS have chosen different approaches which has led to a 'mixed bag' of results. Kastens and Newig [52], for instance, noted that stakeholder processes created a shared commitment to possible solutions which they illustrated in a German case study. The issues identified in this study: who to involve, the added value of increased trust, the appropriate scale at which to address issues and the difficulty of identifying a common interest have been raised by other authors in regard to other countries and regions too $[19,21,22,53-56]$. Several authors report that stakeholder involvement can result in more efficient programmes of measures [21,54], but not in all cases [57]. As the OECD (Organisation for Economic Co-operation and Development) (2014) explains, a party has to have a specific interest at stake if it is to become engaged.

Several authors $[12,54,58]$ take a critical stance towards the normative view of stakeholder participation being an 'all good thing'. They identify that the literature so far has been dominated by normative values on stakeholder participation and less on underlying mechanisms and specific circumstances, although there are some examples described $[22,52,59,60]$. Others $[8,11,22,60-63]$ describe how political dynamics, different rationalities and framing can all limit the scope for participation. Hüesker and Moss [23] found that not all actors in a river basin management approach are positioned to act on different scales, due to e.g., limitations in human or financial resources, not all actions are open to some actors, while other actors make use of the window of opportunities set by this rescaling. This 'problem of fit' can be recognised in other river basins as well [64,65].

The effectiveness of stakeholder involvement is often valued in terms of process effectiveness (output) rather than the resulting effect on the ecosystem that is under discussion (outcome) [66], because of the difficulties of linking stakeholder processes to outcomes $[7,53,54,59]$. One of these difficulties is the time-lag of the ecosystem's response to interventions by stakeholders. As a consequence, it may take many years before the ecological effects of a stakeholder process can be evaluated.

\section{Conceptualisation of the Interactions between Perspectives}

The description of the ecological, legal and social-economic perspectives shows that, although shared elements can be found, e.g., the ecological and legal perspective on effectiveness, differences and interactions in the characteristics and means of the three perspectives are apparent as well (see Table 1). Proper functioning of these interactions could be an important condition in realising effective water quality governance from all three perspectives.

To answer the central question in this study, we have systematically analysed the interactions that potentially exist between these three perspectives and how they could work in the cyclic approach 
of the WFD. This resulted in an initial conceptual framework of interacting perspectives. Figure 1 visualises the interactions between the different perspectives. Taking the ecology of the water system as the starting point for identifying water quality issues, that would ideally set boundary conditions for the legal framework (\#1 in Figure 1) [24] and thus flag the need to identify explicit ecological and chemical objectives and issues that can be valued and discussed in a wider arena. At the same time, other social-economic developments impose demands on the normative framework to be anchored in the legal framework and where the legal framework should offer room for specific standards, measures or circumstances or not (\#2 in Figure 1) [43,67-69]. Edelenbos et al. [70] describe the characteristics of the co-production of knowledge between civil servants, experts and stakeholders which must be in place if any impact on the decision-making process is to be had. A planning process that has not opened itself up to the involvement of stakeholders at an early stage could easily culminate in 'fact fighting' by knowledge coalitions [71] and thus hamper measures to improve water quality.
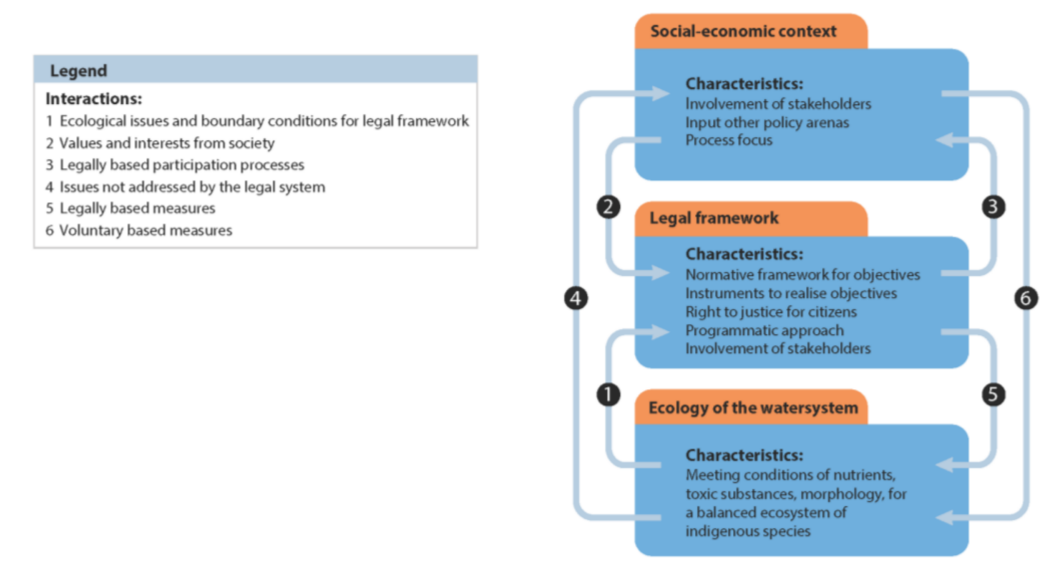

Figure 1. Governance facilitating interactions between the water system, legal framework and social-economic context to increase effectiveness of water quality governance and ecological objectives.

The legal perspective as such interacts between ecological objectives and legitimate decision-making. The water quality issues that are not addressed in the legal framework have to be implicitly addressed in the social-economic context, balanced with other values and other interests (\#4 in Figure 1). The legal framework guarantees that stakeholder participation, access to information and access to justice are available and requires explicit motivation in the decision-making process in regard to how the interests of stakeholders have been taken into account (\#3 in Figure 1) [44]. The social-economic context and the legal framework together provide conditions for developing measures and realising water quality objectives (\#5, \#6 in Figure 1).

\section{Results of Literature Review: Exploring Perspectives' Interactions}

We explored the interactions in the conceptual framework using results from the literature review. Table 2 summarizes the results. Sixty-four of the 122 papers studied use two or more perspectives to discuss effectiveness and thus, possibly, discuss the interactions between these perspectives. 
Table 2. No. of papers with one or more perspectives on effectiveness of water quality governance (review time-frame January 2000-September 2017).

\begin{tabular}{cc}
\hline Perspective & No. of Papers \\
\hline Ecological & 4 \\
Legal & 11 \\
Social-economic & 43 \\
Ecological and legal & 6 \\
Ecological and socio-economic & 33 \\
Legal and social-economic & 17 \\
Ecological, legal and social-economic & 8 \\
Total no. of papers & 122 \\
\hline
\end{tabular}

\subsection{Legal and Ecological Interactions}

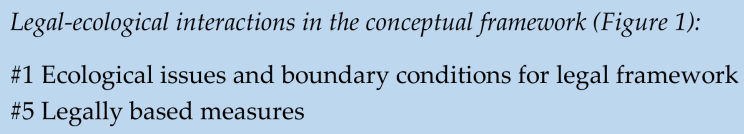

Six papers in the review describe both legal and ecological perspectives on the effectiveness of water quality governance. Legal and ecological perspectives meet in identifying ecological issues, setting the boundary conditions for the legal framework (interaction \#1) and measures taken based upon that legal base (interaction \#5). Gani and Scrimgeour [72] and Tan [73] conclude that the 'rule of $l^{\prime} w^{\prime}$ and 'regulatory quality' are negatively and significantly correlated to water pollution based upon comparative studies of national scale indicators in over 100 countries. No specific references are made regarding the conditions for this interaction to function in these studies. Chiang et al. [74] describe the requirements for effect-based monitoring to ensure sustainable management of the river ecosystem. This is an important condition for the interactions between the legal and the ecological perspectives in order to identify issues, sources of pollution, monitor the effects of measures and to make adaptions based upon these results.

The EC reported that most MS have deficiencies regarding monitoring [75] and methods for assessing and classifying the status of water bodies [9]. To what extent the legal anchoring of objectives has taken place varies between MS [10]. Baaner [6] concludes that the mode of implementation could affect effectiveness, based upon an assessment of WFD implementation in the Scandinavian countries. Similar experiences have been described for Canada [76] and Chile [74] and eleven European countries (Netherlands, Luxembourg, Belgium, France, Germany, United Kingdom, Denmark, Romania, Italy, Spain and Portugal) [10].

A comparable example can be found in the Netherlands regarding the objectives for nutrients in heavily modified local/regional water bodies [77]. Ecological objectives and related physical-chemical objectives are set at a regional scale in river basin management plans to accommodate regional circumstances. These values tend to be much lower (up to 4 times lower) than the nitrate objectives set by the European Nitrate Directive (91/676/EEC), that are based upon the usage of water resources for drinking water supply and the prevention of eutrophication (Annex I). The Nitrate Directive has been implemented in the Netherlands in a complex framework of national law and policy rules [78]. Although significant progress has been made since its implementation, realisation of the objectives of the Nitrate Directive has turned out to be very difficult, mainly due to the intensity of the Dutch agricultural practices [79]. The much more stringent regional nutrient objectives are not related to these national rules and, as a consequence, these objectives have to be realised by specific regional policies and voluntary-based measures [80]. 


\subsection{Social-Economic and Ecological Interactions}

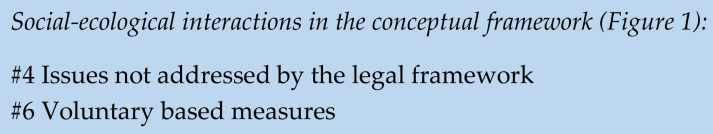

Thirty-three papers in the review describe both social-economic and ecological perspectives on the effectiveness of water quality governance. Social-economic and ecological perspectives meet for those issues that are not, or cannot, be addressed by the legal framework (interaction \#4). This can be the case for new issues of unknown sources of pollution, with a high degree of uncertainty, or for issues with different interests at stake. This results in a status quo in the political debate and, because of this, limited formal ambitions, leaving much of the water quality objectives to be realised by voluntary-based measures (interaction \#6). This knowledge domain is also referred to as 'social-ecology'.

As the understanding of ecosystems is often limited, assessment and management are thought to be best addressed by a process of collaborative learning, in order to collect insights into a system's behaviour and to adapt management interventions to this increased level of understanding. This 'adaptive' governance has been described in many publications (e.g., $[7,28,81,82])$ and is the foundation of the WFD planning process. To date, reports on adaptive governance have focused on the effectiveness of the working process and the link to water quality improvement seems to be lacking. A recent survey of all regional water authorities [83] in the Netherlands, for instance, demonstrated that, on a regional scale, the existing WFD-based monitoring networks are inadequate for identifying specific sources of pollution. In order to discuss effective measures with other actors, this type of information is indispensable and thus an important condition for the interactions between the ecological and social-economic perspectives to function.

Conditions described as important for the working process are: a strong incentive (shared sense of urgency) and lead actor, a balanced trade-off between different values and interests, sufficient financial means and the participation of relevant stakeholders [22,53,84] (e.g., Germany, France, United Kingdom, USA). The use of legally based interventions may be perceived as a drawback in the stakeholder process in some situations, forcing this process into a specific direction [84]. However, this could also be the design of the legislative framework [85]. Other scholars explain the importance of having a balanced representation of stakeholders with different interests at the table, at different stages of the governance process [19,23] (Germany, United Kingdom). Lah et al. [86], in this regard, describe a case study in South Korea, which did not have ecological and social-economic perspectives aligned in the planning phase, causing poor results to be obtained in the implementation phase.

\subsection{Social-Economic and Legal Interactions}

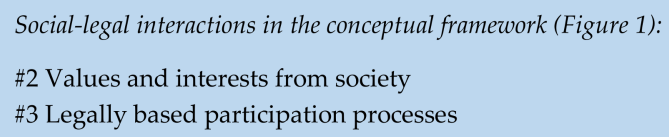

Seventeen papers in the review describe both social-economic and legal perspectives on the effectiveness of water quality governance. Social-economic and legal perspectives meet in the 'mandated participatory planning' stage [66] as set by the WFD (interaction \#3) and issues in the context of water governance which influence the ambitions being anchored in the legal framework (interaction \#2). The interaction between social-economic and legal perspectives facilitates incorporation of the concepts of equity, legitimacy and access to justice in the water quality governance process. Its effectiveness is often valued in terms of process effectiveness and information flow $[23,54,66]$ rather than water quality improvement.

The development of the European directives shows that increased focus is being put on this interaction because of the awareness that water quality issues cannot be addressed by legislation 
alone and need to be fed by local knowledge about specific circumstances and the participation of other stakeholders. Different studies have described this shift $[15,16,43,87]$, which can be seen beyond Europe as well $[13,88]$ (Australia, USA). Several authors cite the importance of taking into account the wider context of other policy arenas (e.g., economic interests) when addressing water quality issues in order to create a common interest for stakeholders to base their participation on and to take action [26,56,89] (Europe, USA). For this reason, Woodhouse and Muller [12] call for a 'problem-shed' rather than a 'water-shed' design of water governance processes. Such approaches seem to be better suited to balance water issues with other interests.

The importance of including other values and interests in the water quality governance process has been described in other publications as well $[59,90,91]$ (United Kingdom, Belgium, Australia). On a local scale, some successful experiences are described with this wider context approach $[45,92]$ (Netherlands, Belgium, USA), but the involvement of different institutional levels and scales within a river basin seems to hamper this process [93-95] (Australia, USA, China), which underlines the importance of having connective capacity between institutional levels and authorities in different regions within river basins [64] (The Netherlands). In all the papers on legal and social-economic perspectives studied, the resulting effects on water quality improvement remain unclear, although the implications of other interests and their influence on the design of the legal framework could be considerable as they have the potential to block problem-solving activities.

Behagel and Turnhout [61], for example, describe the dominant role of other interests within the debate on the mode of the implementation of the WFD in the Netherlands. An exploration of the possible future consequences of WFD implementation for the agricultural sector [96] informed a strong political debate on the level of ambition to be pursued and resulted in the Dutch political choice that the WFD implementation should not lead to additional costs for the agricultural sector (Parliamentary Papers 2002, 27,625 Water Policy, Amendment Van der Vlies No. 92) despite the explicit obligation in the WFD to recover the costs for water services also from the agricultural sector [42]. This resulted in a mode of implementation of the WFD in which the existing general rules on the use of manure and pesticides, based upon the Nitrate Directive, are insufficient for meeting ecological objectives in regional water bodies $[80,97]$.

\subsection{Ecological, Legal and Social-Economic Interactions}

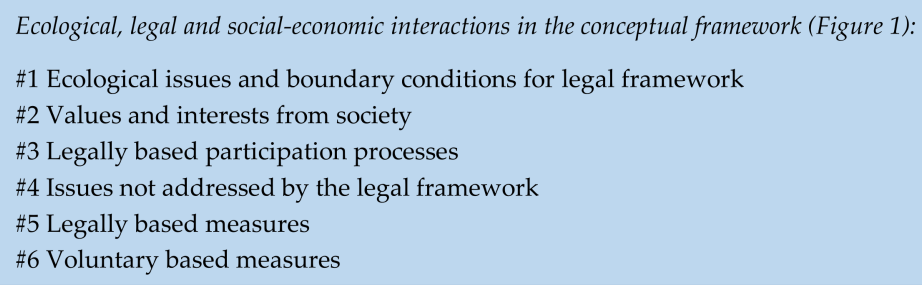

Eight papers use all three perspectives (in some form) to discuss effectiveness and some of the interactions between the perspectives; however, not all perspectives are used in a systemic way. The topics described in the papers can be roughly divided into two groups. Water quality challenges are described on an aggregated level for countries or continents (Germany, Ukraine, China, United States, Australia) [84,98-102], but more conceptual aspects of the governance of complex water quality issues can also be found $[81,84,103,104]$ (USA, Hungary, Europe). The empirical studies focus mostly on the high-level characterisation of the water quality issues (e.g., China [99]), in some cases followed by an identification of the driving forces of pollution [98] (Ukraine), but with few links to the legal anchoring (interaction \#1) and little information on measures and their effects on water quality improvement (interactions \#5 and \#6). Several authors report that effectiveness increases if indirect effects are taken into account, e.g., equity aspects like income loss caused by agricultural measures taken to reduce nutrients emissions [84,105] (USA, Australia) (interactions \#2 and \#4). The lack of a coherent legal and institutional framework is frequently mentioned as a factor limiting the realisation 
of this ambition (e.g., [100-102] (USA, Australia, Germany) (interactions \#1 and \#4). Venues for action are described on a generic level (not related to specific circumstances in a water system) and their (expected) effects in terms of water quality improvement are not described or are only described in a generic way $[84,100]$ (USA) (interactions \#5 and \#6). It is difficult, therefore, based on these studies, to distinguish the effects of these interventions from the social-economic context and legal framework on water quality improvement.

Moreover, the complexity of the ecological response to measures could blur results even if most legal requirements are met. A typical example of this is the status assessment for water bodies, as it is based on the 'one out, all out' principle: this assessment leaves out early recovery of the ecosystem and as such does not necessarily reflect the actual ecological quality. As a consequence, this could result in an over- or underestimation of the actual ecological state of the water body [57] (Italy).

\section{Discussion}

In this study, we have analysed the ecological, legal and social-economic perspectives on the effectiveness of water quality governance and examined how these perspectives interact in order to realise water quality improvement. Although shared elements can be found, differences and interactions in the characteristics and means of the three perspectives are apparent as well (see Table 1). Based upon the results of the literature review, we explored whether this approach offers any insights that complement existing analytical frameworks on water quality governance and that would enable policy-makers and water managers to identify relevant interventions in order to move forward in the restoration and preservation of freshwater ecosystems. We have focussed our analysis on the ecological objectives of the WFD (Article 4). This implies however that issues related to environmental equity are not yet analysed explicitly. Since these issues could play an important role in the process of implementation, it would be very relevant to carry out further research on how environmental equity relates to the realisation of water quality objectives.

\subsection{Results from the Conceptualisation and Literature Review}

Table 3 summarizes the results from our conceptualisation and literature review. The table shows that, for all interactions, one or more conditions are described in the literature studied. The review holds case studies from all continents (see Supplementary Materials). As the scope of the review has its limitations (exclusion of grey literature and non-English papers), it cannot be concluded that all known conditions have been identified, but the results do give an indication of the gaps in literature to date. What is most prominent in Table 3 is that, for all the conditions described, the indication of how the interaction may contribute to water quality improvement is weak or missing in literature so far. However, for the purpose of water quality improvement, it is important to know what the sources of pollution are, what interventions in the water system could lead to water quality improvement and, therefore, who the relevant actors are (authorities and private actors) who should be involved in order to make this happen. In addition, knowledge of the different values and interests of the actors and their possible effects on water quality improvement or deterioration could support the debate on shared ambitions and help to set realistic goals for water quality improvement in time. 
Table 3. Summary of interactions and current understanding on the conditions for these interactions from literature.

\begin{tabular}{|c|c|c|c|c|}
\hline \multicolumn{3}{|c|}{ Conceptualisation of Interactions } & \multicolumn{2}{|c|}{ Results from Literature Review on Interactions } \\
\hline$\#$ & Interaction & Between & Conditions & $\begin{array}{l}\text { Contribution to Water } \\
\text { Quality Improvement }\end{array}$ \\
\hline 1 & $\begin{array}{l}\text { Ecological issues and } \\
\text { boundary conditions for } \\
\text { legal framework }\end{array}$ & Ecological-Legal & $\begin{array}{ll}\text { - } & \text { Coherent legal and } \\
\text { institutional framework } \\
\text { - } \quad \text { Take indirect sources of } \\
\text { pollution into account }\end{array}$ & Not identified \\
\hline 2 & $\begin{array}{c}\text { Legally based participation } \\
\text { processes }\end{array}$ & Social-economic-Legal & $\begin{array}{ll}\text { - } & \text { Balanced representation } \\
\text { of stakeholders }\end{array}$ & Not identified \\
\hline 3 & $\begin{array}{l}\text { Values and interests } \\
\text { from society }\end{array}$ & Social-economic-Legal & $\begin{array}{l}\text { Create a common interest for } \\
\text { stakeholders to participate and } \\
\text { take action } \\
\text { - Use wider context (e.g., } \\
\text { economic interests) to } \\
\text { create engagement } \\
\text { - } \quad \text { Legitimate decision-making }\end{array}$ & $\begin{array}{l}\text { Increased effectiveness } \\
\text { identified, yet not specified }\end{array}$ \\
\hline 4 & $\begin{array}{l}\text { Issues not addressed by the } \\
\text { legal framework }\end{array}$ & Ecological-social-economic & $\begin{array}{ll}\text { - } & \text { Strong incentive } \\
\text { - } & \text { Lead actor } \\
\text { - } & \text { Participation of stakeholders } \\
\text { - } & \text { A balanced trade-off with } \\
& \text { other interests } \\
\text { - } & \begin{array}{l}\text { Adaptive capacity of the } \\
\text { governance framework }\end{array} \\
\end{array}$ & $\begin{array}{l}\text { Increased effectiveness } \\
\text { identified, yet not specified }\end{array}$ \\
\hline 5 & Legally based measures & Ecological-Legal & $\begin{array}{l}\text { - Presence of a legal framework, } \\
\text { mode of implementation } \\
\text { - } \quad \text { Effect-based monitoring } \\
\end{array}$ & $\begin{array}{l}\text { Increased effectiveness } \\
\text { identified, yet not specified }\end{array}$ \\
\hline 6 & Voluntary-based measures & Ecological-social-economic & $\begin{array}{ll}\text { - } & \text { A balanced trade-off with } \\
\text { other interests } \\
\text { - } & \text { Sufficient financial means } \\
\text { - } & \text { Effect-based monitoring } \\
\text { - } & \text { Adaptive capacity of the } \\
\text { governance framework }\end{array}$ & $\begin{array}{l}\text { Increased effectiveness } \\
\text { identified, yet not specified }\end{array}$ \\
\hline
\end{tabular}

\subsection{Conceptualisation Compared to an Existing Framework for Good Water Governance}

To answer the question as to whether this approach offers any new insights, we have compared the conceptualisation to an existing analytical framework for good water governance [27], paying explicit attention to implementation as well. The results of this comparison are shown in Figure 2. In this figure, the conceptualisation of Figure 1 has been complemented with the elements of sustainable water governance from an existing analytical framework [27]. Some of these elements can be specifically attributed to the social-economic, legal or ecological system, and others to some of the interactions, but not all interactions are fully covered by the elements of sustainable water governance. The elements of sustainable water governance also seem to focus on the planning phase rather than the implementation phase, e.g., the development, design, realisation, monitoring and enforcement of measures and their foundation (legally based or voluntary-based), although the identification of ecological issues and setting boundary conditions for the legal framework does not seem to have an explicit role yet either.

These observations could explain why several studies describe practices of good governance, while the effect on water quality remains unclear [73,104,105]. Further analysis of the interactions related to problem definition (\#1 in Figure 2) and measures (\#5 and \#6 in Figure 2) therefore seems to be an interesting aspect to pursue if our understanding of the conditions producing effective water quality governance is to improve. Empirical research into these interactions on the scale of water bodies with a history of water quality governance, in both planning and implementation, could offer valuable information on this. The literature to date is less explicit on the conditions for these interactions. Interventions are often described in general terms, which omits any potential effect on a local water body (e.g., [100]). The fact that ecological effectiveness can only be valued on the scale of a waterbody if we are to understand the mechanisms and to adapt them, sets a challenge to interactions with the legal framework and the social-economic context that operate on other scales as well. Both the legal framework and the social-economic context apply on multiple levels, from local to national to international, and interact at these levels with other contextual factors that could influence water quality. 
Because of this multidimensional nature of water quality governance there can be no 'one-size-fits-all' solution $[28,106]$ but a systematic analysis of interactions can identify the gaps that need to be filled for a governance approach to be coherent and effective for water quality improvement for a specific water system under specific circumstances. Instead of introducing a new analytical framework and adding it to the wide range of existing analytical frameworks for good governance, we recommend taking these frameworks to the next level by connecting the individual elements to the contribution they each make to water quality improvement, in a preferably (semi) quantitative way and extending the frameworks with the interactions between the different perspectives, especially those related to problem definition and the development and realisation of measures.

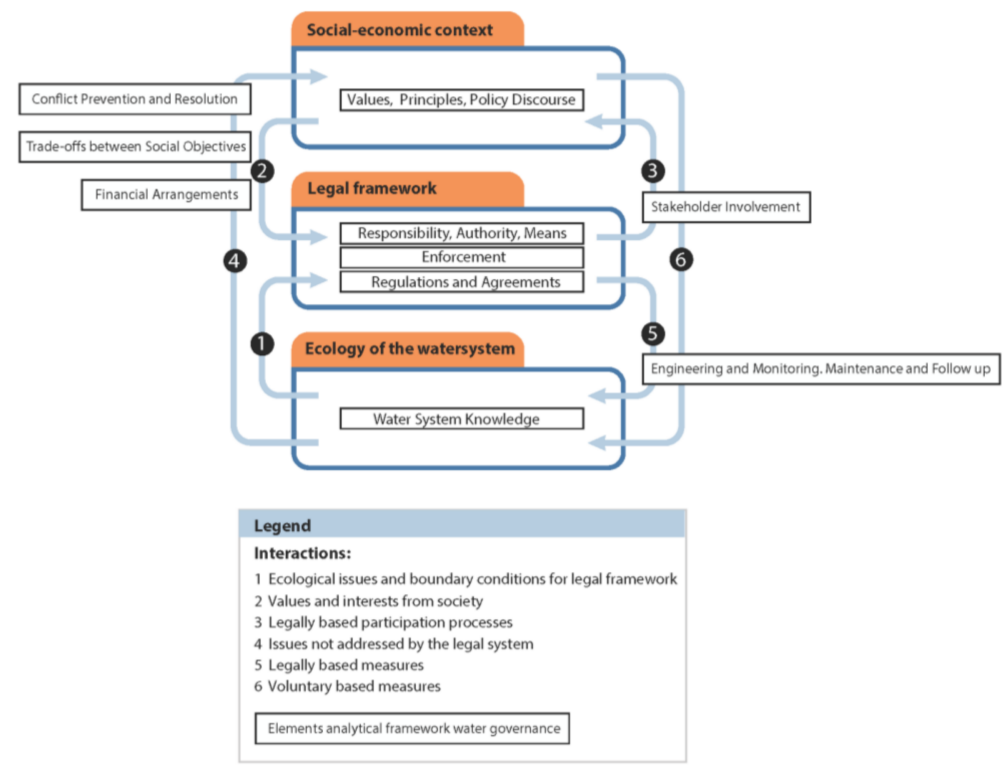

Figure 2. How do elements of an existing analytical framework for water governance [27] relate to the conceptualisation of the interactions between the water system, legal framework and social-economic context (this study)?

\section{Conclusions and Recommendations}

Worldwide, countries face the multifaceted challenge of restoring and preserving aquatic ecosystems in accordance with one of the UN Sustainable Development Goals (SDG 6). Over the last few decades, governance approaches have often been used to realise these ambitions. So far, scholars have identified that it is difficult to relate governance approaches to water quality improvement and have offered several different explanations for this. As ecological, legal and social-economic scholars may hold different perspectives regarding the effectiveness of a governance approach, we have analysed these perspectives, how they interact and how these interactions affect water quality governance. To this end we built a conceptual framework to explain these interactions and carried out a systematic literature review to identify the current level of understanding of these interactions and identify any possible gaps.

Ecological, legal and social-economic perspectives on the effectiveness of water quality governance have both similarities and differences. Potentially conflicting characteristics are: the difficulty of setting objectives (many unknowns) and adequate measures from the ecological perspective, the limited adaptive capacity of the legal framework once set in place and the focus on decision-making processes rather than water quality improvement from the social-economic perspective.

All three perspectives are relevant to the governance approach to water quality improvement and have to interact. The examples described show that the absence of interaction can result in the hampering of water quality improvement. The literature review demonstrates that there is currently 
a gap in the understanding of these interactions and their effects on water quality improvement, especially in regard to the identification of ecological issues and their boundary conditions for the legal framework as well as the identification and follow-up on measures or interventions. The review also revealed that there is a focus in the scientific debate on the planning rather than the implementation phase. As such, the analysis of social-economic, legal and ecological perspectives and their interactions does offer new and additional insights into the conditions required for effective water quality governance.

The conceptualisation employed in this study does not, explicitly, cover all the elements of good water governance, so one of the steps forward could be made by incorporating the interactions into existing analytical frameworks, especially related to problem definition and the development and realisation of measures. Additional improvement can be made by analysing the contribution of the individual elements of water governance to water quality improvement, in a preferably (semi) quantitative way, for instance to answer the question on what the influence of other policy arenas (e.g., agriculture) on water quality might be or the question who to involve, who not and at what moment in time. This would enable policy-makers and water managers to identify relevant interventions and move forward in the restoration and preservation of freshwater ecosystems.

As the non-alignment of social-economic, legal and ecological perspectives on the effectiveness of water quality governance could well be an explanation for the hampering of water quality improvement experienced in the EU WFD implementation so far [9], it would be valuable to study these perspectives and their interactions in different case study settings. Empirical research into these interactions on the scale of water bodies with a history of water quality governance, in both planning and implementation, could offer valuable information.

Supplementary Materials: The following are available online at http:/ /www.mdpi.com/2071-1050/10/4/914/s1, S1: Results literature review.

Acknowledgments: The authors would like to thank the anonymous reviewers for their valuable comments on earlier versions of this article.

Author Contributions: Susanne Wuijts, Peter P. J. Driessen and Helena F. M. W. van Rijswick designed the research. Susanne Wuijts set up the conceptualisation and analysed the literature. Peter P. J. Driessen and Helena F. M. W. van Rijswick reflected upon the results. All authors contributed to the writing process of the paper. All authors read and approved the final manuscript.

Conflicts of Interest: The authors received no financial support for the research and/or authorship of this article. The authors declare no conflict of interest.

\section{References}

1. Hering, D.; Borja, A.; Carstensen, J.; Carvalho, L.; Elliott, M.; Feld, C.K.; Heiskanen, A.S.; Johnson, R.; Moe, J.; Pont, D.; et al. The European Water Framework Directive at the age of 10: A critical review of the achievements with recommendations for the future. Sci. Total Environ. 2010, 408, 4007-4019. [CrossRef] [PubMed]

2. Brack, W.; Altenburger, R.; Schüürmann, G.; Krauss, M.; López Herráez, D.; Van Gils, J.; Slobodnik, J.; Munthe, J.; Gawlik, B.; Van Wezel, A.; et al. The solutions project: Challenges and responses for present and future emerging pollutants in land and water resources management. Sci. Total Environ. 2015, 503-504, 22-31. [CrossRef] [PubMed]

3. Van Kempen, J.J.H. Countering the obscurity of obligations in European environmental law, illustrated by an analysis of article 4 of the European Water Framework Directive. J. Environ. Law 2012, 24, 499-533. [CrossRef]

4. Van Kempen, J.J.H. Obligations of the Water Framework Directive: Dealing with Problems of Interpretation; Edward Elgar Publishing: London, UK, 2014.

5. Kastens, B.; Newig, J. The Water Framework Directive and agricultural nitrate pollution: Will great expectations in Brussels be dashed in Lower Saxony? Eur. Environ. 2007, 17, 16. [CrossRef]

6. Baaner, L. Programmes of measures under the Water Framework Directive-A comparative case study. Nord. Environ. Law J. 2011, 1, 22. 
7. Blackstock, K.L.; Waylen, K.A.; Dunglinson, J.; Marshall, K.M. Linking process to outcomes-Internal and external criteria for a stakeholder involvement in river basin management planning. Ecol. Econ. 2012, 77, 113-122. [CrossRef]

8. Dieperink, C.; Raadgever, G.T.; Driessen, P.P.J.; Smit, A.A.H.; Van Rijswick, H.F.M.W. Ecological ambitions and complications in the regional implementation of the Water Framework Directive in the Netherlands. Water Policy 2012, 14, 160-173. [CrossRef]

9. EC. The EU Environmental Implementation Review: Common Challenges and How to Combine Efforts to Deliver Better Results; European Commission: Brussels, Belgium, 2017; p. 15.

10. Keessen, A.M.; Van Kempen, J.J.H.; Van Rijswick, H.F.M.W.; Robbe, J.; Backes, C.W. European river basin districts: Are they swimming in the same implementation pool? J. Environ. Law 2010, 22, 197-221. [CrossRef]

11. Le Bourhis, J.P. The politics of green knowledge: A comparative study of support for and resistance to sustainability and environmental indicators. J. Comp. Policy Anal. 2016, 18, 403-418. [CrossRef]

12. Woodhouse, P.; Muller, M. Water governance-An historical perspective on current debates. World Dev. 2017, 92, 225-241. [CrossRef]

13. Hart, B.T. The Australian Murray-Darling Basin Plan: Factors leading to its successful development. Ecol. Hydrobiol. 2016, 16, 229-241. [CrossRef]

14. Green, O.; Garmestani, A.; Van Rijswick, H.F.M.W.; Keessen, A.M. EU water governance: Striking the right balance between regulatory flexibility and enforcement? Ecol. Soc. 2013, 18, 11. [CrossRef]

15. Howarth, W. Water pollution and water quality-Shifting regulatory paradigms. In Handbook on Water Law and Policy; Howarth, W., Rieu-Clarke, A., Allen, A., Hendry, S., Eds.; Routlegde: Abingdon, UK, 2017.

16. Lee, M. Law and governance of water protection policy. In EU Environmental Governance; Scott, J., Ed.; Oxford University Press: Oxford, UK, 2009.

17. EC. Common Implementation Strategy for the Water Framework Directive (2000/60/ec). Guidance Document no. 3. Analysis of Pressures and Impacts; EC: Luxemburg, 2003.

18. Lange, P.; Driessen, P.P.J.; Sauer, A.; Bornemann, B.; Burger, P. Governing towards sustainability: Conceptualizing modes of governance. J. Environ. Policy Plan. 2013, 15, 403-425. [CrossRef]

19. Blackstock, K.L.; Waylen, K.A.; Marshall, K.M.; Dunglinson, J. Hybridity of representation: Insights from river basin management planning in Scotland. Environ. Plan. C Gov. Policy 2014, 32, 549-566. [CrossRef]

20. Edelenbos, J.; Bressers, N.; Scholten, P. Water Governance as Connective Capacity; Ashgate Publishing Limited: Farnham, UK, 2013.

21. Graversgaard, M.; Jacobsen, B.H.; Kjeldsen, C.; Dalgaard, T. Stakeholder engagement and knowledge co-creation in water planning: Can public participation increase cost-effectiveness? Water 2017, 9. [CrossRef]

22. Borowski, I.; Le Bourhis, J.P.; Pahl-Wostl, C.; Barraqué, B. Spatial misfit in participatory river basin management: Effects on social learning, a comparative analysis of German and French case studies. Ecol. Soc. 2008, 13, 7. [CrossRef]

23. Hüesker, F.; Moss, T. The politics of multi-scalar action in river basin management: Implementing the EU Water Framework Directive (WFD). Land Use Policy 2015, 42, 38-47. [CrossRef]

24. Chapron, G.; Epstein, Y.; Trouwborst, A.; López-Bao, J.V. Bolster legal boundaries to stay within planetary boundaries. Nat. Ecol. Evol. 2017, 1. [CrossRef] [PubMed]

25. Graversgaard, M.; Thorsøe, M.H.; Kjeldsen, C.; Dalgaard, T. Evaluating public participation in Denmark's water councils: How policy design and boundary judgements affect water governance! Outlook Agric. 2016, 45. [CrossRef]

26. OECD. OECD Principles on Water Governance (Daegu Declaration); OECD: Paris, France, 2015.

27. Van Rijswick, H.F.M.W.; Edelenbos, J.; Hellegers, P.; Kok, M.; Kuks, S. Ten building blocks for sustainable water governance: An integrated method to assess the governance of water. Water Int. 2014, 39, 725-742. [CrossRef]

28. Ostrom, E.; Janssen, M.A.; Anderies, J.M. Going beyond panaceas. Proc. Natl. Acad. Sci. USA 2007, 104, 15176-15178. [CrossRef] [PubMed]

29. Folke, C.; Biggs, R.; Norström, A.V.; Reyers, B.; Rockström, J. Social-ecological resilience and biosphere-based sustainability science. Ecol. Soc. 2016, 21, 41. [CrossRef]

30. Kramm, J.; Pichler, M.; Schaffartzik, A.; Zimmermann, M. Societal relations to nature in times of crisis-Social ecology's contributions to interdisciplinary sustainability studies. Sustainability 2017, 9. [CrossRef] 
31. Fischer-Kowalski, M.; Weisz, H. Society as hybrid between material and symbolic realms: Toward a theoretical framework of society-nature interaction. Adv. Hum. Ecol. 1999, 8, 215-251.

32. Stokols, D.; Hall, K.; Vogel, A. Transdisciplinary public health: Core characteristics, definitions and strategies for success. In Transdisciplinary Public Health: Research, Methods and Practice; Haire-Joshu, D., McBride, T., Eds.; Jossey-Bass Publishers: San Francisco, CA, USA, 2013; pp. 3-30.

33. Boeuf, B.; Fritsch, O. Studying the implementation of the water framework directive in Europe: A meta-analysis of 89 journal articles. Ecol. Soc. 2016, 21. [CrossRef]

34. Mellor, H.; Verbeek, S.; Van de Wijngaart, T. Ecological Key Factor. A Method for Setting Realistic Goals and Implementing Cost-Effective Measures for the Improvement of Ecological Water Quality; STOWA: Amersfoort, The Netherlands, 2017; p. 34.

35. Hoekstra, A.Y.; Mekonnen, M.M. The water footprint of humanity. Proc. Natl. Acad. Sci. USA 2012, 109, 3232-3237. [CrossRef] [PubMed]

36. Munthe, J.; Brorström-Lundén, E.; Rahmberg, M.; Posthuma, L.; Altenburger, R.; Brack, W.; Bunke, D.; Engelen, G.; Gawlik, B.M.; Van Gils, J.; et al. An expanded conceptual framework for solution-focused management of chemical pollution in European waters. Environ. Sci. Eur. 2017, 29, 13. [CrossRef] [PubMed]

37. Houtman, C.J. Emerging contaminants in surface waters and their relevance for the production of drinking water in Europe. J. Integr. Environ. Sci. 2010, 7, 271-295. [CrossRef]

38. Brack, W.; Dulio, V.; Ågerstrand, M.; Allan, I.; Altenburger, R.; Brinkmann, M.; Bunke, D.; Burgess, R.M.; Cousins, I.; Escher, B.; et al. Towards the review of the European Union Water Framework management of chemical contamination in European surface water resources. Sci. Total Environ. 2017, 576, 720-737. [CrossRef] [PubMed]

39. ICPR. Internationally Coordinated Management Plan for the International River Basin District of the Rhine; International Commission for the Protection of the Rhine: Koblenz, Germany, 2009.

40. EC. A Blueprint to Safeguard Europe's Water Resources; EC: Brussels, Belgium, 2012.

41. Zingraff-Hamed, A.; Greulich, S.; Wantzen, K.; Pauleit, S. Societal drivers of European water governance: A comparison of urban river restoration practices in France and Germany. Water 2017, 9, 206. [CrossRef]

42. Lindhout, P.E. Cost Recovery as a Policy Instrument to Achieve Sustainable and Equitable Water Use in Europe and the Netherlands. Ph.D. Thesis, Utrecht University, The Netherlands, 27 March 2015.

43. Van Holten, S.; Van Rijswick, H.F.M.W. The governance approach in European Union environmental directives and its consequences for flexibility, effectiveness and legitimacy. In EU Environmental Legislation: Legal Perspectives on Regulatory Strategies; Peeters, M., Uylenburg, R., Eds.; Edward Elgar Publishing: Cheltenham, UK, 2014; pp. 13-47.

44. EC. Commission Notice on Access to Justice in Environmental Matters; European Commission: Brussels, Belgium, 2017; p. 65.

45. Suykens, C. The Law of the River. The Institutional Challenge for Transboundary River Basin Management and Multi-Level Approaches to Water Quantity Management. Ph.D. Thesis, KU Leuven and Utrecht University, Leuven, Belgium, 2 October 2017.

46. Van Rijswick, H.F.M.W.; Gilissen, H.K.; Van Kempen, J.J.H. The need for international and regional transboundary cooperation in European river basin management as a result of new approaches in EC water law. ERA Forum 2010, 11, 129-157. [CrossRef]

47. UNECE. Convention on Access to Information, Public Participation in Decision-Making and Access to Justice in Environmental Matters; UNECE: Aarhus, Denmark, 1998; p. 25.

48. Orr, C.J.; Adamowski, J.F.; Medema, W.; Milot, N. A multi-level perspective on the legitimacy of collaborative water governance in Québec. Can. Water Resour. J. Rev. Cana. Ressour. Hydr. 2015, 41, 353-371. [CrossRef]

49. Peter, F. Political legitimacy. Available online: https://plato.stanford.edu/archives/sum2017/entries/ legitimacy/ (accessed on 13 November 2017).

50. Jonsson, A. Public participation in water resources management: Stakeholder voices on degree, scale, potential, and methods in future water management. Ambio J. Hum. Environ. 2005, 34, 495-500. [CrossRef]

51. Roggero, M. Shifting troubles: Decision-making versus implementation in participatory watershed governance. Environ. Policy Gov. 2013, 23, 63-74. [CrossRef]

52. Kastens, B.; Newig, J. Will participation foster the successful implementation of the Water Framework Directive? The case of agricultural groundwater in Northwest Germany. Local Environ. 2008, 13, $27-41$. [CrossRef] 
53. Newig, J.; Fritsch, O. Environmental governance: Participatory, multi-level-And effective? Environ. Policy Gov. 2009, 19, 197-214. [CrossRef]

54. Benson, D.; Fritsch, O.; Cook, H.; Schmid, M. Evaluating participation in WFD river basin management in England and Wales: Processes, communities, outputs and outcomes. Land Use Policy 2014, 38, $213-222$. [CrossRef]

55. Hammer, M.; Balfors, B.; Mörtberg, U.; Petersson, M.; Quin, A. Governance of water resources in the phase of change: A case study of the implementation of the EU Water Framework Directive in Sweden. Ambio J. Hum. Environ. 2011, 40, 210-220. [CrossRef]

56. Moss, T. Spatial fit, from panacea to practice: Implementing the EU Water Framework Directive. Ecol. Soc. 2012, 17, 12. [CrossRef]

57. Prato, S.; La Valle, P.; De Luca, E.; Lattanzi, L.; Migliore, G.; Morgana, J.G.; Munari, C.; Nicoletti, L.; Izzo, G.; Mistri, M. The "one-out, all-out" principle entails the risk of imposing unnecessary restoration costs: A study case in two Mediterranean coastal lakes. Mar. Pollut. Bull. 2014, 80, 30-40. [CrossRef] [PubMed]

58. Van der Heijden, J.; Ten Heuvelhof, E. The mechanics of virtue: Lessons on public participation from implementing the Water Framework Directive in the Netherlands. Environ. Policy Gov. 2012, 22, 177-188. [CrossRef]

59. Waylen, K.A.; Blackstock, K.L.; Marshall, K.B.; Dunglinson, J. Participation-prescription tension in natural resource management: The case of diffuse pollution in Scottish water management. Environ. Policy Gov. 2015, 25, 111-124. [CrossRef]

60. Taylor, K.A.; Short, A. Integrating scientific knowledge into large-scale restoration programs: The CALFED Bay-Delta program experience. Environ. Sci. Policy 2009, 12, 674-683. [CrossRef]

61. Behagel, J.; Turnhout, E. Democratic legitimacy in the implementation of the Water Framework Directive in the Netherlands: Towards participatory and deliberative norms? J. Environ. Policy Plan. 2011, 13, 297-316. [CrossRef]

62. Stirling, A. "Opening up" and "closing down" power, participation, and pluralism in the social appraisal of technology. Sci. Technol. Hum. Values 2008, 33, 33. [CrossRef]

63. Behagel, J.; Arts, B. Democratic governance and political rationalities in the implementation of the Water Framework Directive in the Netherlands. Public Adm. 2014, 92, 291-306. [CrossRef]

64. Wuijts, S.; Driessen, P.P.J.; Van Rijswick, H.F.M.W. Governance conditions for improving quality drinking water resources: The need for enhancing connectivity. Water Resour. Manag. 2017, 32, 1245-1260. [CrossRef]

65. Vatn, A.; Vedeld, P. Fit, Interplay, and Scale: A Diagnosis. Ecol. Soc. 2012, 17, 12. [CrossRef]

66. Newig, J.; Gaube, V.; Berkhoff, K.; Kaldrack, K.; Kastens, B.; Lutz, J.; Schlußmeier, B.; Adensam, H.; Haberl, H. The role of formalisation, participation and context in the success of public involvement mechanisms in resource management. Syst. Pract. Action Res. 2008, 21, 423-441. [CrossRef]

67. Andersson, I.; Petersson, M.; Jarsjö, J. Impact of the European Water Framework Directive on local-level water management: Case study Oxunda Catchment, Sweden. Land Use Policy 2012, 29, 73-82. [CrossRef]

68. De Leon, P. The missing link revisited: Contemporary implementation research. Policy Stud. Rev. 1999, 16, 311-338. [CrossRef]

69. Runhaar, H.A.C.; Dieperink, C.; Driessen, P.P.J. Policy analysis for sustainable development. The toolbox for the environmental social scientist. Int. J. Sustain. High. Educ. 2006, 7, 34-56. [CrossRef]

70. Edelenbos, J.; Van Buuren, A.; Van Schie, N. Co-producing knowledge: Joint knowledge production between experts, bureaucrats and stakeholders in Dutch water management projects. Environ. Sci. Policy 2011, 14, 675-684. [CrossRef]

71. Van Buuren, A.; Edelenbos, J. Conflicting knowledge; why is joint knowledge production such a problem? Sci. Public Policy 2004, 31, 289-299. [CrossRef]

72. Gani, A.; Scrimgeour, F. Modeling governance and water pollution using the institutional ecological economic framework. Econ. Model. 2014, 42, 363-372. [CrossRef]

73. Tan, X. Environment, governance and GDP: Discovering their connections. Int. J. Sustain. Dev. 2006, 9, 311-335. [CrossRef]

74. Chiang, G.; Munkittrick, K.R.; McMaster, M.E.; Barra, R.; Servos, M. Regional cumulative effects monitoring framework: Gaps and challenges for the Biobío river basin in South Central Chile. Gayana 2014, 78, 109-119. [CrossRef] 
75. Beijen, B.A.; Van Rijswick, H.F.M.W.; Anker, H.T. The importance of monitoring for the effectiveness of environmental directives, a comparison of monitoring obligations in European environmental directives. Utrecht Law Rev. 2014, 10, 10. [CrossRef]

76. Cook, C. Governing jurisdictional fragmentation: Tracing patterns of water governance in Ontario, Canada. Geoforum 2014, 56, 192-200. [CrossRef]

77. Keessen, A.M.; Runhaar, H.A.C.; Schoumans, O.F.; Van Rijswick, H.F.M.W.; Driessen, P.P.J.; Oenema, O.; Zwart, K.B. The need for flexibility and differentiation in the protection of vulnerable areas in EU environmental law: The implementation of the Nitrates Directive in the Netherlands. Eur. Environ. Plan. Law 2011, 8, 141-164. [CrossRef]

78. Van Rijswick, H.F.M.W.; Havekes, H.J.M. European and Dutch Water Law; Europa Law Publishing: Groningen, The Netherlands, 2012.

79. EC. Report on the Implementation of Council Directive 91/676/EEC Concerning the Protection of Waters against Pollution Caused by Nitrates from Agricultural Sources Based on Member State Reports for the Period 2008-2011; EC: Brussels, Belgium, 2013; p. 11.

80. Freriks, A.; Keessen, A.M.; Korsse, D.; Van Rijswick, H.F.M.W.; Bastmeijer, K. As Far as the Own Instruments Reach: A Study on the Position of the Province of North-Brabant and the North-Brabant Water Authorities in the Realisation of the Water Framework Objectives, with Special Attention to the New Dutch Environmental Act (in Dutch); Utrecht University: Utrecht, The Netherlands; University of Tilburg: Utrecht, The Netherlands, 2016; p. 94.

81. Pahl-Wostl, C.; Jeffrey, P.; Sendzimir, J. Adaptive and integrated management of water resources. In Water Resources Planning and Management; Cambridge University Press: Cambridge, UK, 2011; pp. 292-310.

82. Huitema, D.; Mostert, E.; Egas, W.; Moellenkamp, S.; Pahl-Wostl, C.; Yalcin, R. Adaptive water governance: Assessing the institutional prescriptions of adaptive (co-)management from a governance perspective and defining a research agenda. Ecol. Soc. 2009, 14, 19. [CrossRef]

83. Collombon, M.; Peet, M. Inventory Knowledge Needs on Water Quality (in Dutch); STOWA: Amersfoort, The Netherlands, 2017; p. 88, 2017-17.

84. Smith, L.E.D.; Porter, K.S. Management of catchments for the protection of water resources: Drawing on the New York City watershed experience. Reg. Environ. Chang. 2010, 10, 311-326. [CrossRef]

85. Buijze, A. Promoting sustainable water management in area development. J. Water Law 2015, 24, 166-173.

86. Lah, T.J.; Park, Y.; Cho, Y.J. The four major rivers restoration project of South Korea: An assessment of its process, program, and political dimensions. J. Environ. Dev. 2015, 24, 375-394. [CrossRef]

87. Scott, J.; Trubek, D.M. Mind the gap: Law and new approaches to governance in the European Union. Eur. Law J. 2002, 8, 18. [CrossRef]

88. Huber-Stearns, H.R.; Cheng, A.S. The evolving role of government in the adaptive governance of freshwater social-ecological systems in the Western US. Environ. Sci. Policy 2017, 77, 40-48. [CrossRef]

89. Mauerhofer, V.; Hubacek, K.; Coleby, A. From polluter pays to provider gets: Distribution of rights and costs under payments for ecosystem services. Ecol. Soc. 2013, 18. [CrossRef]

90. Crabbé, A. Analysis of the Effectiveness of Water Policy in Flanders (in Dutch); Flemish Environmental Agency: Aalst, Belgium, 2017.

91. Wright, I.A.; Belmer, N.; Davies, P.J. Coal mine water pollution and ecological impairment of one of Australia's most 'protected' high conservation-value rivers. Water Air Soil Pollut. 2017, 228. [CrossRef]

92. Steiger-Meister, K.; Becker, D.R. Using policy to promote participatory planning: An examination of Minnesota's Lake Improvement Districts from the citizen perspective. J. Environ. Plan. Manag. 2012, 55, 599-615. [CrossRef]

93. Ross, A.; Connell, D. The evolution and performance of river basin management in the Murray-Darling Basin. Ecol. Soc. 2016, 21, 326-355. [CrossRef]

94. Scholz, J.T.; Stiftel, B. Adaptive Governance and Water Conflict: New Institutions for Collaborative Planning; Resources for the Future: Washington, DC, USA, 2005; pp. 1-274.

95. Wang, X.; Ongley, E.D. Transjurisdictional water pollution disputes and measures of resolution: Examples from the Yellow River Basin, China. Water Int. 2004, 29, 282-289. [CrossRef]

96. Van der Bolt, F.J.E.; Van den Bosch, R.; Brock, T.C.M.; Hellegers, P.J.G.J.; Kwakernaak, C.; Leenders, D.; Schoumans, O.F.; Verdonschot, P.F.M. AQUAREIN; the Consequenses of the EU WFD for Agriculture, Nature, Recreation and Fishery (in Dutch); Alterra: Wageningen, The Netherlands, 2003. 
97. IenM. River basin Management Plans (2016-2021) in the Netherlands; IenM: The Hague, The Netherlands, 2015.

98. Hagemann, N.; Blumensaat, F.; Tavares Wahren, F.; Trümper, J.; Burmeister, C.; Moynihan, R.; Scheifhacken, N. The long road to improving the water quality of the Western Bug River (Ukraine)—A multi-scale analysis. J. Hydrol. 2014, 519, 2436-2447. [CrossRef]

99. Jin, X.; Lu, S.; Hu, X.; Jiang, X.; Wu, F. Control concept and countermeasures for shallow lakes' eutrophication in China. Front. Environ. Sci. Eng. China 2008, 2, 257-266. [CrossRef]

100. Wardropper, C.B.; Chang, C.; Rissman, A.R. Fragmented water quality governance: Constraints to spatial targeting for nutrient reduction in a Midwestern USA watershed. Landsc. Urban Plan. 2015, 137, 64-75. [CrossRef]

101. Webb, A.A.; Martin, P.V. Potential of a payments for ecosystem services scheme to improve the quality of water entering the Sydney catchments. Water Policy 2016, 18, 91-110. [CrossRef]

102. Richter, S.; Völker, J.; Borchardt, D.; Mohaupt, V. The Water Framework Directive as an approach for integrated water resources management: Results from the experiences in Germany on implementation, and future perspectives. Environ. Earth Sci. 2013, 69, 719-728. [CrossRef]

103. Mihók, B.; Biró, M.; Molnár, Z.; Kovács, E.; Bölöni, J.; Erős, T.; Standovár, T.; Török, P.; Csorba, G.; Margóczi, K.; et al. Biodiversity on the waves of history: Conservation in a changing social and institutional environment in Hungary, a post-soviet EU Member State. Biol. Conserv. 2017, 211, 67-75. [CrossRef]

104. Knieper, C.; Pahl-Wostl, C. A comparative analysis of water governance, water management, and environmental performance in river basins. Water Resour. Manag. 2016, 30, 2161-2177. [CrossRef]

105. Metcalf, S.J.; Dambacher, J.M.; Rogers, P.; Loneragan, N.; Gaughan, D.J. Identifying key dynamics and ideal governance structures for successful ecological management. Environ. Sci. Policy 2014, 37, 34-49. [CrossRef]

106. Pahl-Wostl, C.; Lebel, L.; Knieper, C.; Nikitina, E. From applying panaceas to mastering complexity: Towards adaptive water governance in river basins. Environ. Sci. Policy 2012, 23, 24-34. [CrossRef]

(C) 2018 by the authors. Licensee MDPI, Basel, Switzerland. This article is an open access article distributed under the terms and conditions of the Creative Commons Attribution (CC BY) license (http://creativecommons.org/licenses/by/4.0/). 